\title{
Front Matter: Volume 6715
}

, "Front Matter: Volume 6715," Proc. SPIE 6715, Optomechatronic Actuators and Manipulation III, 671501 (10 October 2007); doi: 10.1117/12.778065

Event: International Symposium on Optomechatronic Technologies, 2007, SPIE. Lausanne, Switzerland 


\title{
PROCEEDINGS OF SPIE
}

\section{Optomechatronic Actuators and Manipulation III}

\author{
Yves Bellouard \\ Yukitoshi Otani \\ Kee S. Moon \\ Editors
}

8-10 October 2007

Lausanne, Switzerland

Organized by

Ecole Polytechnique Fédérale de Lausanne (Switzerland)

Sponsored by

LIST-Laboratoire d'Intégration des Systèmes et des Technologies, CEA (France)

CSEM-Centre Suisse d'Electronique et de Microtechnique SA (Switzerland)

IMT-Institut de microtechnique (France)

Olympus (Switzerland)

Taylor \& Francis Group (United Kingdom)

Cooperating Organizations

FSRM-Fondation Suisse pour la Recherche en Microtechnique (Switzerland)

SPIE

Published by

SPIE

Volume 6715

Proceedings of SPIE, 0277-786X, v. 6715 
The papers included in this volume were part of the technical conference cited on the cover and title page. Papers were selected and subject to review by the editors and conference program committee. Some conference presentations may not be available for publication. The papers published in these proceedings reflect the work and thoughts of the authors and are published herein as submitted. The publisher is not responsible for the validity of the information or for any outcomes resulting from reliance thereon.

Please use the following format to cite material from this book:

Author(s), "Title of Paper," in Optomechatronic Actuators and Manipulation III, edited by Yves Bellouard, Yukitoshi Otani, Kee S. Moon, Proceedings of SPIE Vol. 6715 (SPIE, Bellingham, WA, 2007) Article CID Number.

ISSN 0277-786X

ISBN 9780819468635

Published by

SPIE

P.O. Box 10, Bellingham, Washington $98227-0010$ USA

Telephone +1 3606763290 (Pacific Time) · Fax +1 3606471445

SPIE.org

Copyright (c) 2007, Society of Photo-Optical Instrumentation Engineers

Copying of material in this book for internal or personal use, or for the internal or personal use of specific clients, beyond the fair use provisions granted by the U.S. Copyright Law is authorized by SPIE subject to payment of copying fees. The Transactional Reporting Service base fee for this volume is $\$ 18.00$ per article (or portion thereof), which should be paid directly to the Copyright Clearance Center (CCC), 222 Rosewood Drive, Danvers, MA 01923. Payment may also be made electronically through CCC Online at copyright.com. Other copying for republication, resale, advertising or promotion, or any form of systematic or multiple reproduction of any material in this book is prohibited except with permission in writing from the publisher. The CCC fee code is $0277-786 \mathrm{X} / 07 / \$ 18.00$.

Printed in the United States of America.

Publication of record for individual papers is online in the SPIE Digital Library.

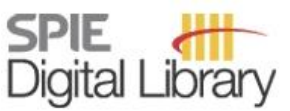

SPIEDigitalLibrary.org

Paper Numbering: Proceedings of SPIE follow an e-First publication model, with papers published first online and then in print and on CD-ROM. Papers are published as they are submitted and meet publication criteria. A unique, consistent, permanent citation identifier (CID) number is assigned to each article at the time of the first publication. Utilization of CIDs allows articles to be fully citable as soon they are published online, and connects the same identifier to all online, print, and electronic versions of the publication. SPIE uses a six-digit CID article numbering system in which:

- The first four digits correspond to the SPIE volume number.

- The last two digits indicate publication order within the volume using a Base 36 numbering system employing both numerals and letters. These two-number sets start with $00,01,02,03,04,05$, $06,07,08,09,0 \mathrm{~A}, 0 \mathrm{~B} \ldots \mathrm{OZ}$, followed by 10-1Z, 20-2Z, etc.

The CID number appears on each page of the manuscript. The complete citation is used on the first page, and an abbreviated version on subsequent pages. Numbers in the index correspond to the last two digits of the six-digit CID number. 


\title{
Contents
}

\author{
vii Conference Committee \\ ix Symposium Committee \\ xi Introduction
}

SESSION 1 ACTUATORS FOR OPTICAL BEAM STEERING, FOCUSING, AND SHAPING

671502 Optical beam steering using a 2D MEMS scanner [6715-01]

Y. Pétremand, P.-A. Clerc, Univ. of Neuchâtel (Switzerland); M. Epitaux, Intel Corp. (USA);

R. Hauffe, Hymite GmbH (Germany); W. Noell, N. F. de Rooij, Univ. of Neuchâtel

(Switzerland)

671503 Parallel robots in a ground-based telescope active optics system: theory and experiments [6715-02]

P. Schipani, L. Ferragina, L. Marty, A. Grado, INAF (Italy); L. Di Fiore, INFN (Italy); R. De Rosa, A. La Rana, Univ. degli Studi di Napoli Federico II (Italy); A. Busatta, European Industrial Engineering (Italy)

671504 Micromirror arrays for object selection [6715-03]

S. Waldis, Univ. of Neuchâtel (Switzerland); F. Zamkotsian, Lab. d'Astrophysique de Marseille (France); P.-A. Clerc, M. Zickar, W. Noell, N. de Rooij, Univ. of Neuchâtel (Switzerland)

671505 Thermo-optic variable blazed grating for beam steering [6715-04]

M. T. Johnson, G. S. Seetharaman, Air Force Institute of Technology (USA)

671506 Mechanism for passive thermal compensation in harsh environment [6715-05]

A. Gelman, E. Maliah, Elbit Systems Electro-Optics Elop (Israel)

671507 Development of auto focus actuator for camera phone by applying piezoelectric single crystal [6715-06]

M.-J. Chung, Y.-H. Yee, D.-H. Cha, Korea Polytechnic Univ. (South Korea)

671508 Light actuated speaker: high efficiency conversion from light energy to acoustic sound energy [6715-08]

R. Hamamura, International Christian Univ. (Japan); T. Yamamoto, Univ. of Massachusetts (USA); H. Okamura, International Christian Univ. (Japan)

671509 Dynamic characterization and damping control of a MEMS structure [6715-09]

I. Veryeri, I. Basdogan, Koc Univ. (Turkey)

$67150 \mathrm{~A}$ Laser actuated shape memory alloy mobile micro-robot: initial results [6715-10]

P.-J. van den Broek, Eindhoven Univ. of Technology (Netherlands); B. Potsaid, Rensselaer Polytechnic Institute (USA); Y. Bellouard, Eindhoven Univ. of Technology (Netherlands);

J. T. Wen, Rensselaer Polytechnic Institute (USA) 
6715 OB Design of a PMN-PT-based monolithic nanomanipulator [6715-11]

K. S. Moon, J. Yi, San Diego State Univ. (USA); Y. K. Hong, Touchdown Technologies, Inc. (USA); J. A. L. Mathers, San Diego State Univ. (USA)

6715 OC Low order high accuracy deformable mirror based on electromagnetic actuators [6715-13] F. P. Wildi, West Switzerland Univ. of Applied Science (Switzerland) and Observatoire de Genève (Switzerland); G. Mühlebach, T. Maulaz, West Switzerland Univ. of Applied Science (Switzerland)

6715 OD Generation and consideration of vectorial vortex array [6715-14]

Y. Otani, Tokyo Univ. of Agriculture and Technology (Japan); T. Wakayama, Saitama Medical Univ. (Japan); N. Umeda, Tokyo Univ. of Agriculture and Technology (Japan); T. Yoshizawa, Saitama Medical Univ. (Japan)

\section{SESSION 2 OPTICAL-BASED MICROMANIPULATION AND RELATED DETECTION AND TRACKING SYSTEMS}

$6715 \mathrm{OE}$ Optimal design of adaptive optics based systems using high fidelity MEMS deformable mirror models [6715-15]

B. Potsaid, J. T. Wen, Rensselaer Polytechnic Institute (USA)

6715 OF MEMS tunable polymer grating for advantageous spectroscopic measurements [6715-17] S. C. Truxal, K. Kurabayashi, Y.-C. Tung, Univ. of Michigan (USA)

6715 OG Proposing a novel scheme for optical manipulation of objects using interference of two laser beams of different wavelengths [6715-18]

S. Maruyama, T. Tagami, H. Okamura, International Christian Univ. (Japan)

$6715 \mathrm{OH}$ In-situ optical detection of mesoscale components in glass microfluidic channel with monolithic waveguide [6715-20]

V. K. Pahilwani, Y. Bellouard, Eindhoven Univ. of Technology (Netherlands); A. A. Said, M. Dugan, P. Bado, Translume (USA)

\section{SESSION 3 OPTICAL-BASED ACTUATION AND MICROASSEMBLY OF OPTICAL COMPONENTS}

6715 ol Light-driven polymer auto-oscillators [6715-21]

L. Huey, M. J. Curley, Alabama Agricultural and Mechanical Univ. (USA); S. S. Sarkisov, SSS Optical Technologies, LLC (USA); J. C. Wang, Alabama Agricultural and Mechanical Univ. (USA)

$67150 \mathrm{~J}$ Development of two arm micromanipulator for handling and assembling of minute objects in fixed view by use of pantograph mechanisms [6715-22] M. Horie, D. Kamiya, Tokyo Institute of Technology (Japan); M. Kouno, N. Mochizuki, Y. Yoda, A. Higaki, NISCA Co., Ltd. (Japan); M. Nakamura, Tokyo Medical and Dental Univ. (Japan)

6715 OK Micro-optical components assembly for the fabrication of a miniaturized optoelectronic transducer [6715-23]

P. Corradi, Scuola Superiore Sant'Anna (Italy); L. Ascari, IMT Doctoral School in Biorobotics (Italy); A. Menciassi, C. Laschi, Scuola Superiore Sant'Anna (Italy) 
$6715 \mathrm{OL}$ Three-dimensional optical control of magnetic levitation by temperature sensitive ferrite [6715-24]

Y. Otani, Y. Mizutani, N. Umeda, Tokyo Univ. of Agriculture and Technology (Japan)

Author Index 
Downloaded From: https://www.spiedigitallibrary.org/conference-proceedings-of-spie on 25 Apr 2023

Terms of Use: https://www.spiedigitallibrary.org/terms-of-use 


\title{
Conference Committee
}

\author{
Conference Chair
}

Yves Bellouard, Technische Universität Eindhoven (Netherlands)

Conference Cochairs

Yukitoshi Otani, Tokyo University of Agriculture and Technology (Japan)

Kee S. Moon, San Diego State University (USA)

Program Committee

Masaaki Adachi, Kanazawa University (Japan)

Kallol Bhattacharya, University of Calcutta (India)

Ridha Ben Mrad, University of Toronto (Canada)

Katsushi Furutani, Toyota Technological Institute (Japan)

Nobuyuki Hashimoto, Citizen Watch Company, Ltd. (Japan)

Dae Hwa Jeong, LG Electronics Inc. (South Korea)

Pavel Krecmer, Dublin City University (Ireland)

Timothy P. Kurzweg, Drexel University (USA)

Sung-Q Lee, Electronics and Telecommunications Research Institute (South Korea)

Toru Yoshizawa, Saitama Medical University (Japan)

Young Soo Park, Argonne National Laboratory (USA)

Sergey S. Sarkisov, SSS Optical Technologies, LLC (USA)

Moustapha Hafez, CEA LIST (France)

Benjamin Potsaid, Rensselaer Polytechnic Institute (USA)

Gleb Vdovin, Technische Universiteit Delft (The Netherlands)

Tom Stevenson, University of Edinburgh (United Kingdom)

Philippe Bado, Translume, Inc. (USA)

\section{Session Chairs}

1 Actuators for Optical Beam Steering, Focusing, and Shaping

Yukitoshi Otani, Tokyo University of Agriculture and Technology (Japan)

2 Optical-based Micromanipulation and Related Detection and Tracking Systems

Kee S. Moon, San Diego State University (USA)

3 Optical-based Actuation and Microassembly of Optical Components

Philippe Bado, Translume, Inc. (USA) 
Downloaded From: https://www.spiedigitallibrary.org/conference-proceedings-of-spie on 25 Apr 2023

Terms of Use: https://www.spiedigitallibrary.org/terms-of-use 


\section{International Symposium on Optomechatronic Technologies ISOT 2007}

In recent years, most engineered products, processes, and systems have been evolving towards higher functionality, flexibility, intelligence, and miniaturization. This trend is stimulated by the ongoing fusion between optical and mechatronic technologies leading not only to enhanced performance but also to the creation of new, innovative functionalities. Because of its synergistic effect, the integration of these engineering fields, labeled optomechatronic technology, is becoming a major driving force to future enabling technologies.

The objective of this symposium is to gather researchers and engineers working in the field of optomechatronics and to provide them with a forum for discussion for exchanging their points of view and experience and sharing their research results through high quality peer reviewed papers.

The symposium consists of five conferences:

1) Optomechatronic Actuators and Manipulation

2) Optomechatronic Sensors and Instrumentation

3) Optomechatronic Micro / Nano Devices and Components

4) Optomechatronic Computer-Vision Systems

5) Optomechatronic Systems Control

Symposium Chair

Jean-Marc Breguet, Swiss Federal Institute of Technology, Lausanne (Switzerland)

Symposium Cochairs

Hyungsuck Cho, Korea Advanced Institute of Science and Technology (South Korea)

Shun'ichi Kaneko, Hokkaido University (Japan)

Yoshitada Katagiri, The University of Tokyo (Japan)

Jonathan Kofman, University of Waterloo (Canada) and University of Ottawa (Canada)

George K. Knopf, The University of Western Ontario (Canada)

Rainer Tutsch, Technische Universität Braunschweig (Germany)

John T. Wen, Center of Automation Technologies and Systems,

Rensselaer Polytechnic Institute (USA) 


\section{Steering Committee}

Hyungsuck Cho, Korea Advanced Institute of Science and Technology (South Korea)

George K. Knopf, The University of Western Ontario (Canada)

Farrokh Janabi-Sharifi, Ryerson University (Canada) and University of Tabriz (Iran)

Jonathan Kofman, University of Waterloo (Canada) and University of Ottawa (Canada)

Katsuo Kurabayashi, University of Michigan (USA)

Kee S. Moon, San Diego State University (USA)

Rainer Tutsch, Technische Universität Braunschweig (Germany)

Shun'ichi Kaneko, Hokkaido University (Japan)

Yasuhiro Takaya, Osaka University (Japan)

Yoshitada Katagiri, The University of Tokyo (Japan)

Yukitoshi Otani, Tokyo University of Agriculture and Technology (Japan)

Toru Yoshizawa, Saitama Medical University (Japan) 


\section{Introduction}

There has been a rapid growth in actuation and manipulation research in the past few years dedicated to optomechatronic applications. Many novel materials, architectures, and applications have been proposed, built, and studied. The goal of this conference is to keep a record of the state-of-the-art research in this fast moving area. This conference is designed to fulfill the need for closer collaboration between researchers, academics, manufacturers, and end users by bringing them together in a single forum to interact, exchange technical knowledge, and discuss their experiences.

This year, three oral sessions are organized around the following topics:

- Actuators for optical beam steering, focusing, and shaping

- Optical based micro-manipulation, related detection means, and tracking systems

- Optical-based actuation and microassembly of optical components.

In addition, a special dedicated poster session presents recent developments in the field of optomechatronic actuators and manipulation. This session plays an important role in the conference as it will give a unique opportunity to authors and participants to exchange ideas in an informal and convivial atmosphere.

\section{Yves Bellouard Yukitoshi Otani Kee S. Moon}


Downloaded From: https://www.spiedigitallibrary.org/conference-proceedings-of-spie on 25 Apr 2023

Terms of Use: https://www.spiedigitallibrary.org/terms-of-use 